\title{
GROWTH AND REPRODUCTION PERFORMANCE OF JAPANESE QUAILS (Coturnix coturnix japonica) UNDER VARIOUS ENVIRON- MENTS OF LIGHT COLORS
}

\author{
Hassan E. Elkomy, Ayman E. Taha*, Heba A. Basha, Magda I. Abo-Samaha, \\ Mohamed M. Sharaf \\ Department of Animal Husbandry and Animal wealth Development, Faculty of Veterinary \\ Medicine, Alexandria University, Egypt
}

*Corresponding author, E-mail: ayman_soma2007@yahoo.com

\begin{abstract}
Light colors are important environmental factors affecting growth and reproductive performance of Japanese Quails. In the current study, a total number of 1060 of Japanese quail chicks were used to assess the effect of white, red, and green light color on body weight, age of sexual maturity, laying parameters as well as responses of reproductive organs. Results revealed that Japanese quails reared under red color light had higher $(P<0.05)$ body weight at five weeks of age, relative growth rate $(R G R)$, the first 42 days of egg production, relative ovaries and testicle weights, sperm motility and fertility and hatchability percentages $(243.28 \mathrm{~g}, 184.50 \%, 79.76 \%, 4.33 \%, 4.05 \%, 90.50 \%$, $83.47 \%$ and $83.47 \%$; respectively) than those raised under green and white light colors. Also, quails subjected to red color light during growth reached sexual maturity earlier $(39.34 \mathrm{~d})$ than birds subjected to white and green light colors (44.87 and $48.45 \mathrm{~d}$ ). We conclude that using red light color during the period of growth and laying in Japanese quails improves growth and reproduction performances.
\end{abstract}

Key words: Japanese quails; light colors; growth; reproduction performances

\section{Introduction}

Light is an environmental factor affecting quail production, light stimuli vary by intensity, wavelength, duration and color, all of which aggregate to influence the physiological, production, reproduction as well as behavioral parameters of the birds (1). Poultry have retinal photoreceptors that are responsible for vision, while the non-visual photoreceptors (extra-retinal) are responsible for detecting photoperiod and adapting their physiology to the environment (2). Light stimulates directly the GnRH pathway that increases the amount of gonadotropins, which enhancing the ovarian development. Simultaneously, the increase in day length decreases the amount of melatonin and $\mathrm{GnRH}$, and removing the inhibition on the stimulatory axis. Increased photoperiod enhances the sexual maturity of chicks due to induction of gonadotropin and sex steroids secretion with subsequent increment in production (3).

Interestingly, light color and its wavelength represent important factors that judge the performance of birds. It has been concluded that the red light diminishes cannibalism and feather pecking; blue light has a calming effect; however, orange-red and blue green color light have 
enhancing chicken reproduction and growth (4), respectively. There were variations among the performance parameters of broiler chicks reared under various light intensities (5). However, no improvement was reported in broiler chicks exposed to various intensities of light, although green light color enhanced growth performance of such chicks as compared to orange, red and yellow light (6). However, Kim et al. (7) found that birds performed better when reared under red light without affecting feed conversion ratio (FCR).

Hatchability of quail eggs collected from birds exposed to green bulbs was higher than those subjected to other light treatments $(8,9)$. Meanwhile, quails reared under red and incandescent lights had higher body weight than those reared under blue and green lights (8). The increased photoperiod to enhance the earlier sexual maturity, which may be altered according to the spectral output, Japanese quails exposed to red light reached to sexual maturity two weeks earlier than those exposed to blue or green light (8). Hens reared under red light laid eggs significantly earlier than those under incandescent light and blue light. The mean age at first egg of chicken pullets in red light was earlier by two to eleven days compared to pullets in all other light treatments (6). Similarly, laying hens maintained under red and white lights had early sexual maturity than hens maintained under green light (10). Moreover, light color affects egg numbers of laying hens (7, 10, and 11). This study aimed to investigate effects of light color on growth and reproduction parameters of Japanese quails.

\section{Material and methods}

Experimental design and birds management

This study was performed using 1060 one day old Japanese quail chicks using rearing pens at the Department of Animal Husbandry and Animal Wealth Development, Faculty of Veterinary Medicine, Alexandria University, Egypt. Chicks were randomly distributed into three light treatments (white light $n=426$, red light $n=320$ and green light $n=315$ ). Pens were cleaned, disinfected and fumigated using formaldehyde gas. The chicks were brooded at a temperature of $35^{\circ} \mathrm{C}$ using automatic gas heaters as a source of heat and illumination. Temperature was gradually reduced $3^{\circ} \mathrm{C}$ weekly till reach room temperature $24{ }^{\circ} \mathrm{C}$ at the fifth week of rearing. Birds were placed in environmentally controlled lightproof rooms separated from each other by a wooden chip board. At the fifth week, Japanese quails were moved to wire cages and grouped to sire families. Each family consisted of one male and three females (1:3 sex ratios) according to Karousa et al. (12). Cages were separated by lightproof plastic sheets to prevent transmittance of light. Additionally, all windows were blacked out by light proof plastic sheets.

Birds were fed add-libitum commercial starter diets containing $22 \%$ crude protein and $3100 \mathrm{kcal} / \mathrm{kg}$ of metabolizable energy meeting (13) requirements. While at the laying period, laying diet had calcium content of 3.5\%; the birds also had free access to water. Animals were exposed to $24 \mathrm{~h}$ lighting during the brooding and growing periods. At laying period, the duration of light was adjusted by using a timer to 16 hours light and 8 hours darkness (16 L: 8 D). All light sources were equalized to $9 \mathrm{~W}$. The following light treatment regimens were used. Treatment 1 (White light): A total number of 426 Japanese quail chicks were reared in separate pens under white LED light (W) with wavelength 380 to $770 \mathrm{~nm}$ from hatching till five weeks; the birds were then moved to laying batteries containing 20 sire families illuminated with the same light. Treatment 2 (Red light): 320 Japanese quail chicks were reared in a separate pen illuminated with red LED bulbs (R) with wavelength 618 to $635 \mathrm{~nm}$. At the fifth week, Japanese quails were moved to separate battery containing 28 sire families illuminated with same light. Treatment 2 (Green light): 314 Japanese quail chicks were reared in a pen illuminated green LED bulbs (G) with wavelength 515 to $535 \mathrm{~nm}$. At the fifth week, Japanese quails were moved into laying batteries (14 sire families illuminated with same light). Bird eggs were collected from each treatment (white, red and green) daily and stored for 7 days then disinfected and incubated in previously cleaned and fumigated incubators by spraying TH4® (2 
$\mathrm{ml} /$ liter water) to assess the effect of continuous use of different light colors on hatching performance (hatchability and fertility percentages) of Japanese quail eggs.

\section{Hatching performance}

Fertility $\%=$ (Number of fertile eggs/ Total number of eggs set) $\times 100$

Hatchability of the total eggs $\%=($ Number of hatched chicks/ Total number of eggs set) $\times$ 100

Hatchability of fertile eggs $\%=$ (Number of hatched chicks/ Number of fertile eggs set) $\times$ 100

\section{Growth and reproductive performance}

Birds were weighed at hatch and every week till five weeks of age to the nearest gram using digital scale with accuracy 0.001 g (WANT®), and then the differences between two successive weights were calculated to estimate the relative growth rate according to Brody (14).

Relative growth rate $=(\mathrm{W} 2-\mathrm{W} 1) / 0.5$ $(\mathrm{W} 1+\mathrm{W} 2) \times 100$, Where: $\mathrm{W} 1=$ is the weight at any week and $\mathrm{W} 2=$ is the weight at next week. Age of sexual maturity (age at the first egg) was expressed in days from hatching day till the day of the first egg of the quail hens. Egg production was recorded for each sire family of quails for the first 42 days after complete sexual maturity (15) with the estimation of hen day egg production (HDEP) for the same period.

\section{HDEP $\%=($ Total of eggs produced/ Number of live hens) $\times 100$}

\section{Male and female reproduction organs}

A random sample of three males and three females per treatment were selected at 98 days of age and weighed then slaughtered and dissected for removal of testes and ovaries. The right and left testes were immediately weighed to calculate the gonadosomatic index ( $\mathrm{GI}=$ testes weight /body weight $\mathrm{x}$ 100).

Semen was also collected from vas deferens immediately after slaughtering of males. Sperm motility was then evaluated by two trained evaluators in samples placed on glass slides $\left(37^{\circ} \mathrm{C}\right)$ at $400 \mathrm{x}$ magnifications. Sperm motility was expressed as the percentage of mobile cells. The ovary was immediately weighed and relative weight to live body weight (ovary weight / body weight $\times 100$ ) was calculated.

\section{Statistical analysis}

Data of body weight, weight gain and relative growth rate were analyzed by general linear model (GLM) procedure using SAS (16) according to the following model: $X_{\mathrm{ijk}}=\mu+\mathrm{T}_{\mathrm{i}}+$ $\mathrm{S}_{\mathrm{j}}+\mathrm{D}_{\mathrm{i} * \mathrm{j}}+\mathrm{e}_{\mathrm{ijk}} ; \mu=$ population mean, $\mathrm{T}_{\mathrm{i}}=$ treatment effect (dark, green and red light), $S_{j}=$ sex effect $(M=$ male and $F=$ female $), D_{i * j}=$ the interaction between treatment and $\mathrm{sex}, \mathrm{e}_{\mathrm{ijk}}=$ random errors,

Data of hatchability, fertility, egg quality parameters, egg production, age at sexual maturity and reproductive organ parameters were analyzed by analysis of variance (ANOVA) using SAS (16) and the significance between different treatment groups were assessed using Duncan's test. Prior to analysis, percentages of embryonic mortality were arcsine transformed to corresponding value according to Snedecor and Cochran (17).

\section{Reults and discussion}

\section{Effect of light color on Growth}

The effects of different light colors on body weight of Japanese quails from hatch day till five weeks of age were showed in Table 1. The overall hatch weight was not significantly different between treatment groups. Similarly, this parameter did not differ between the sexes in each group. During the first week, the overall body weight in red light treated birds $(55.25 \mathrm{~g}$ ) was significantly higher than green and white light groups (49.92 and $30.62 \mathrm{~g}$, respectively). Birds reared under red light also had significantly higher overall body weight at the $2^{\text {nd }}, 3^{\text {rd }}$, $4^{\text {th }}$ and $5^{\text {th }}$ week of age $(101.61,160.26,202.38$ and $243.28 \mathrm{~g}$, respectively) than those reared under green and white lights. Females reared under red and white colors recorded significantly higher body weight than males at the $2^{\text {nd }}$, $3^{\text {rd }}, 4^{\text {th }}$ and $5^{\text {th }}$ week of age. In contrast, gender effect was not apparent for green light until $5^{\text {th }}$ week of age. 
Table 1: LS Means \pm SE of body weight for Japanese quails subjected to different treatments of light color

\begin{tabular}{|c|c|c|c|c|c|c|c|}
\hline \multirow{2}{*}{$\begin{array}{l}\text { Light } \\
\text { Group }\end{array}$} & \multirow[t]{2}{*}{ Sex } & \multicolumn{6}{|c|}{ Body weight (g) } \\
\hline & & Hatch & W1 & W2 & W3 & W4 & W5 \\
\hline \multirow{2}{*}{ White } & $\mathrm{F}$ & $9.35 \pm 0.06^{\mathrm{a}}$ & $31.25 \pm 1.27^{\mathrm{a}}$ & $75.62 \pm 0.61^{\mathrm{a}}$ & $120.00 \pm 0.89^{a}$ & $179.41 \pm 1.14^{a}$ & $221.85 \pm 1.32^{\mathrm{a}}$ \\
\hline & M & $9.29 \pm 0.09^{\mathrm{a}}$ & $29.98 \pm 1.86^{\mathrm{a}}$ & $73.38 \pm 0.90^{\mathrm{b}}$ & $114.48 \pm 1.30^{\mathrm{b}}$ & $170.64 \pm 1.67^{\mathrm{b}}$ & $206.41 \pm 1.93^{\mathrm{b}}$ \\
\hline \multicolumn{2}{|c|}{ Overall } & $9.32 \pm 0.05^{\mathrm{A}}$ & $30.62 \pm 1.12^{\mathrm{C}}$ & $74.50 \pm 0.54^{\mathrm{C}}$ & $117.24 \pm 0.79^{\mathrm{C}}$ & $175.02 \pm 1.01^{\mathrm{B}}$ & $214.13 \pm 1.17^{\mathrm{C}}$ \\
\hline \multirow{2}{*}{ Green } & $\mathrm{F}$ & $9.77 \pm 0.11^{\mathrm{a}}$ & $50.04 \pm 2.30^{\mathrm{a}}$ & $92.23 \pm 1.11^{\mathrm{a}}$ & $154.28 \pm 1.61^{\mathrm{a}}$ & $206.45 \pm 2.07^{\mathrm{a}}$ & $246.18 \pm 2.39^{\mathrm{a}}$ \\
\hline & M & $9.63 \pm 0.10^{\mathrm{a}}$ & $49.81 \pm 2.19^{\mathrm{a}}$ & $91.23 \pm 1.06^{\mathrm{a}}$ & $150.80 \pm 1.53^{\mathrm{a}}$ & $201.18 \pm 1.97^{\mathrm{a}}$ & $222.89 \pm 2.28^{\mathrm{b}}$ \\
\hline \multicolumn{2}{|c|}{ Overall } & $9.70 \pm 0.08^{\mathrm{A}}$ & $49.92 \pm 1.59^{\mathrm{B}}$ & $91.73 \pm 0.77^{\mathrm{B}}$ & $152.54 \pm 1.11^{\mathrm{B}}$ & $203.82 \pm 1.43^{\mathrm{A}}$ & $234.54 \pm 1.65^{\mathrm{B}}$ \\
\hline \multirow{2}{*}{ Red } & $\mathrm{F}$ & $9.48 \pm 0.12^{\mathrm{a}}$ & $57.06 \pm 2.47^{\mathrm{a}}$ & $104.46 \pm 1.19^{\mathrm{a}}$ & $164.78 \pm 1.73^{\mathrm{a}}$ & $208.43 \pm 2.22^{\mathrm{a}}$ & $263.19 \pm 2.56^{\mathrm{a}}$ \\
\hline & M & $9.53 \pm 0.12^{\mathrm{a}}$ & $53.44 \pm 2.54^{\mathrm{a}}$ & $98.76 \pm 1.23^{b}$ & $155.75 \pm 1.78^{b}$ & $196.33 \pm 2.29^{b}$ & $223.39 \pm 2.64^{\mathrm{b}}$ \\
\hline \multicolumn{2}{|c|}{ Overall } & $9.50 \pm 0.08^{\mathrm{A}}$ & $55.25 \pm 1.77^{\mathrm{A}}$ & $101.61 \pm 0.85^{\mathrm{A}}$ & $160.26 \pm 1.24^{\mathrm{A}}$ & $202.38 \pm 1.60^{\mathrm{A}}$ & $243.28 \pm 1.89^{\mathrm{A}}$ \\
\hline
\end{tabular}

Overall means carrying different capital letters within the same column are significantly different $(\mathrm{P}<0.05)$

Means carrying different small letters within group within same column are significantly different $(\mathrm{P}<0.05)$

$\mathrm{F}=$ Female, $\mathrm{M}=$ Male, $\mathrm{W}=\mathrm{Week}, \mathrm{LS}$ Mean = least square mean

Table 2: LS Means \pm SE of relative growth rates for Japanese quails subjected to different treatments of light color

\begin{tabular}{|c|c|c|c|c|c|c|c|}
\hline \multirow{2}{*}{$\begin{array}{l}\text { Light } \\
\text { Group }\end{array}$} & \multirow{2}{*}{ Sex } & \multicolumn{6}{|c|}{ Relative growth rate $(\%)$} \\
\hline & & $\mathrm{R} 1$ & $\mathrm{R} 2$ & R3 & $\mathrm{R} 4$ & R5 & R6 \\
\hline \multirow{2}{*}{ White } & $\mathrm{F}$ & $107.29 \pm 0.50^{\mathrm{a}}$ & $82.83 \pm 0.73^{\mathrm{a}}$ & $45.49 \pm 0.46^{\mathrm{a}}$ & $39.70 \pm 0.35^{\mathrm{a}}$ & $21.18 \pm 0.41^{\mathrm{a}}$ & $183.70 \pm 0.12^{\mathrm{a}}$ \\
\hline & M & $104.80 \pm 0.74^{\mathrm{b}}$ & $84.06 \pm 1.07^{\mathrm{a}}$ & $43.69 \pm 0.67^{\mathrm{b}}$ & $39.42 \pm 0.52^{\mathrm{a}}$ & $19.14 \pm 0.60^{\mathrm{b}}$ & $182.71 \pm 0.18^{b}$ \\
\hline \multicolumn{2}{|c|}{ Overall } & $06.04 \pm 0.45^{\mathrm{C}}$ & $83.45 \pm 0.65^{\mathrm{A}}$ & $44.59 \pm 0.41^{\mathrm{B}}$ & $39.56 \pm 0.31^{\mathrm{A}}$ & $20.16 \pm 0.36^{\mathrm{A}}$ & $183.21 \pm 0.11^{\mathrm{B}}$ \\
\hline \multirow{2}{*}{ Green } & $\mathrm{F}$ & $129.13 \pm 0.91^{\mathrm{a}}$ & $59.17 \pm 1.31^{\mathrm{a}}$ & $50.44 \pm 0.83^{\mathrm{a}}$ & $29.04 \pm 0.64^{\mathrm{a}}$ & $17.70 \pm 0.74^{\mathrm{a}}$ & $183.24 \pm 0.21^{\mathrm{a}}$ \\
\hline & M & $131.37 \pm 0.87^{\mathrm{a}}$ & $58.75 \pm 1.26^{\mathrm{a}}$ & $49.26 \pm 0.80^{\mathrm{a}}$ & $28.76 \pm 0.61^{\mathrm{a}}$ & $10.19 \pm 0.71^{\mathrm{b}}$ & $181.73 \pm 0.21^{\mathrm{b}}$ \\
\hline \multicolumn{2}{|c|}{ Overall } & $130.25 \pm 0.63^{\mathrm{B}}$ & $58.96 \pm 0.91^{\text {B }}$ & $49.85 \pm 0.57^{\mathrm{A}}$ & $28.90 \pm 0.44^{\mathrm{B}}$ & $13.94 \pm 0.51^{\mathrm{B}}$ & $182.48 \pm 0.15^{\mathrm{C}}$ \\
\hline \multirow{2}{*}{ Red } & $\mathrm{F}$ & $139.65 \pm 0.98^{a}$ & $59.00 \pm 1.42^{\mathrm{a}}$ & $44.89 \pm 0.90^{\mathrm{a}}$ & $23.41 \pm 0.69^{\mathrm{a}}$ & $23.85 \pm 0.80^{\mathrm{a}}$ & $185.72 \pm 0.23^{\mathrm{a}}$ \\
\hline & M & $137.26 \pm 1.01^{\mathrm{a}}$ & $59.64 \pm 1.46^{\mathrm{a}}$ & $44.87 \pm 0.92^{\mathrm{a}}$ & $23.13 \pm 0.71^{\mathrm{a}}$ & $13.86 \pm 0.82^{\mathrm{b}}$ & $183.26 \pm 0.24^{\mathrm{b}}$ \\
\hline \multicolumn{2}{|c|}{ Overall } & $138.45 \pm 0.70^{\mathrm{A}}$ & $59.32 \pm 1.02^{\mathrm{B}}$ & $44.88 \pm 0.64^{\mathrm{B}}$ & $23.27 \pm 0.49^{\mathrm{C}}$ & $18.85 \pm 0.57^{\mathrm{A}}$ & $184.50 \pm 0.17^{\mathrm{A}}$ \\
\hline
\end{tabular}

Overall means carrying different capital letters within the same column are significantly different $(\mathrm{P}<0.05)$ Means carrying different small letters within group within same column are significantly different $(\mathrm{P}<0.05)$ $\mathrm{F}=$ Female, $\mathrm{M}=$ Male, $\mathrm{W}=\mathrm{Week}, \mathrm{LS}$ Mean = least square mean

Table 3: Means \pm standard errors for sexual maturity of Japanese quails subjected to different treatments of light color

\begin{tabular}{cc}
\hline Treatment/Light Color & Age at first egg (days) \\
\hline White & $44.87 \pm 0.36^{\mathrm{b}}$ \\
Green & $48.45 \pm 0.40^{\mathrm{a}}$ \\
Red & $39.34 \pm 0.21^{\mathrm{c}}$ \\
\hline
\end{tabular}

Means carrying different litters within the same column are significantly different $(\mathrm{P}<0.05)$ 
Table 4: Means \pm standard errors for hen day egg production (HDEP \%) of Japanese quails subjected to different treatments of light color

\begin{tabular}{cccc}
\hline Weeks & \multicolumn{3}{c}{ Treatment } \\
\cline { 2 - 4 } & White & Green & Red \\
\hline Wk1 & $70.47 \pm 4.07^{\mathrm{a}}$ & $64.63 \pm 2.53^{\mathrm{a}}$ & $73.13 \pm 1.63^{\mathrm{a}}$ \\
Wk2 & $69.52 \pm 3.23^{\mathrm{b}}$ & $56.12 \pm 2.13^{\mathrm{c}}$ & $81.29 \pm 1.54^{\mathrm{a}}$ \\
Wk3 & $77.38 \pm 2.39^{\mathrm{a}}$ & $74.15 \pm 1.63^{\mathrm{a}}$ & $79.25 \pm 2.42^{\mathrm{a}}$ \\
Wk4 & $61.19 \pm 3.13^{\mathrm{b}}$ & $60.89 \pm 2.70^{\mathrm{b}}$ & $79.25 \pm 1.38^{\mathrm{a}}$ \\
Wk5 & $78.57 \pm 2.43^{\mathrm{a}}$ & $66.33 \pm 2.42^{\mathrm{b}}$ & $80.27 \pm 1.92^{\mathrm{a}}$ \\
Wk6 & $80.48 \pm 1.54^{\mathrm{b}}$ & $74.83 \pm 1.69^{\mathrm{c}}$ & $85.37 \pm 1.27^{\mathrm{a}}$ \\
Total & $72.94 \pm 1.61^{\mathrm{b}}$ & $66.16 \pm 1.44^{\mathrm{c}}$ & $79.76 \pm 1.00^{\mathrm{a}}$ \\
\hline
\end{tabular}

Means carrying different litters within the same row are significantly different $(\mathrm{P}<0.05)$

Table 5: Means \pm SE for egg weight in grams, external and internal egg quality parameters of Japanese quail eggs subjected to different treatments of light color

\begin{tabular}{cccc}
\hline Parameters & \multicolumn{3}{c}{ Light treatment } \\
\cline { 2 - 4 } & White & Green & Red \\
\hline Egg weight $(\mathrm{g})$ & $14.52 \pm 0.16^{\mathrm{a}}$ & $13.72 \pm 0.15^{\mathrm{b}}$ & $13.26 \pm 0.29^{\mathrm{b}}$ \\
Egg shape index & $78.07 \pm 0.40^{\mathrm{a}}$ & $78.19 \pm 0.52^{\mathrm{a}}$ & $78.50 \pm 0.51^{\mathrm{a}}$ \\
Egg volume & $12.34 \pm 0.31^{\mathrm{a}}$ & $11.52 \pm 0.27^{\mathrm{b}}$ & $11.63 \pm 0.53^{\mathrm{b}}$ \\
Yolk+albumen \% & $78.92 \pm 0.50^{\mathrm{b}}$ & $82.99 \pm 0.29^{\mathrm{a}}$ & $82.23 \pm 0.42^{\mathrm{a}}$ \\
Shell \% & $21.08 \pm 0.98^{\mathrm{a}}$ & $17.01 \pm 0.65^{\mathrm{b}}$ & $17.77 \pm 0.90^{\mathrm{b}}$ \\
Yolk index & $0.46 \pm 0.08^{\mathrm{c}}$ & $0.52 \pm 0.07^{\mathrm{a}}$ & $0.49 \pm 0.09^{\mathrm{b}}$ \\
Haugh unit & $93.02 \pm 0.72^{\mathrm{b}}$ & $95.44 \pm 0.44^{\mathrm{a}}$ & $96.44 \pm 0.60^{\mathrm{a}}$ \\
\hline
\end{tabular}

Means carrying different litters within the same row are significantly different $(\mathrm{P}<0.05)$

Table 6: Means \pm standard errors for relative ovaries, testes and percentage of sperm motility weight of Japanese quails subjected to different treatments of light color for 14 weeks

\begin{tabular}{lccc}
\hline \multirow{2}{*}{ Parameters (\%) } & \multicolumn{3}{c}{ Light Color / Treatment } \\
\cline { 2 - 4 } & White & Green & Red \\
\hline Relative Ovaries weight & $3.43 \pm 0.41^{\mathrm{a}}$ & $4.27 \pm 0.96^{\mathrm{a}}$ & $4.33 \pm 0.18^{\mathrm{a}}$ \\
Relative testes weight & $3.53 \pm 0.30^{\mathrm{a}}$ & $3.47 \pm 0.24^{\mathrm{a}}$ & $4.05 \pm 0.20^{\mathrm{a}}$ \\
Sperm motility & $75.00 \pm 2.89^{\mathrm{b}}$ & $84.33 \pm 7.22^{\mathrm{ab}}$ & $90.50 \pm 1.26^{\mathrm{a}}$ \\
\hline
\end{tabular}

Means carrying different litters within the same row are significantly different $(\mathrm{P}<0.05)$.

Table 7: Means \pm standard errors for fertility, scientific hatchability and commercial hatchability percentages of the first generation of Japanese quail eggs subjected to different treatments of light color

\begin{tabular}{crrr}
\hline \multirow{2}{*}{ Light Color / Treatment } & Fertility (\%) & \multicolumn{2}{c}{ Hatchability (\%) } \\
\cline { 3 - 4 } & & Fertile eggs & Total eggs \\
\hline White & $81.17 \pm 0.44^{\mathrm{b}}$ & $84.80 \pm 0.35^{\mathrm{a}}$ & $77.40 \pm 1.25^{\mathrm{b}}$ \\
Green & $85.37 \pm 0.56^{\mathrm{a}}$ & $86.93 \pm 0.91^{\mathrm{a}}$ & $80.53 \pm 0.62^{\mathrm{a}}$ \\
Red & $90.07 \pm 1.13^{\mathrm{a}}$ & $92.53 \pm 1.27^{\mathrm{a}}$ & $83.47 \pm 0.58^{\mathrm{a}}$ \\
\hline
\end{tabular}

Means carrying different litters within the same column are significantly different $(\mathrm{P}<0.05)$. 


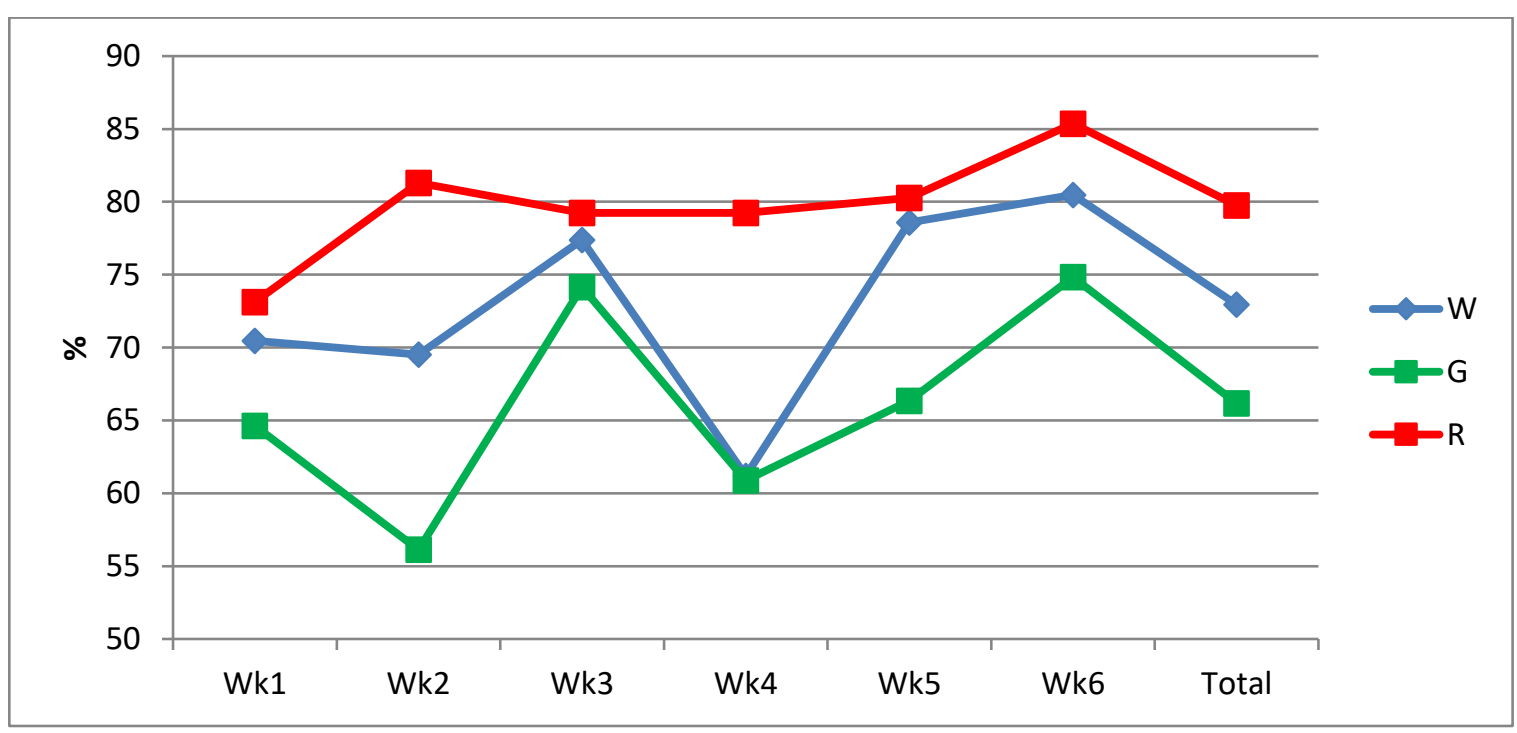

Figure 1: Means for hen day egg production (HDEP \%) of Japanese quails subjected to different treatments of light color

$\mathrm{W}=$ Quails reared under white light from $\mathrm{G}=$ Quails reared under green light from

Data on relative growth rates of Japanese quails subjected to different light colors for five weeks are presented in Table 2. Birds reared under red light grew at significantly higher rate (R6) from zero to five weeks of age (184.50\%) than those reared under white and green light colors (183.21 and 182.48, respectively). Moreover, the overall growth rate of females was significantly higher than that of males in all light treatments.

These results are similar to those reported by others who found that Japanese quails reared under red lights had higher body weight than those reared under blue and green lights after five weeks (8). They speculated this was due to higher weight of reproductive organs as testes weight of male Japanese quail at five weeks of age with red light was double that of green light. Similarly, Li et al. (18) and Reddy et al. (19) reported growth-stimulating effect of red light in laying hens and documented increased weights and activity of reproductive organs (higher weight of the ovary and oviduct and more yellow yolk follicles). In contrast, Baxter et al. (10) found that hens reared under Green light had significantly higher body weight gain than birds under Red and White lights after 23 weeks of age. The sex effect on body weight of
Japanese quail was also reported by (20) and (21) who found that female weights were significantly higher than those of males.

\section{Age at sexual maturity}

The onset of sexual maturity of Japanese quail subjected to different treatments of light color, (based on the age at first egg) was presented in Table 3. Females of Japanese quail reared under red light treatment reached sexual maturity significantly earlier (39.34 d) than those exposed to white light (44.87 d), while significantly late sexual maturity was recorded by females reared under green light (48.45 d). The result agreed with (22) who found that red light induced sexual maturity of broiler breeder birds 7 and 14 days earlier than green and blue light treated respectively. Also, laying hens maintained under red and white light had early sexual maturity than hens maintained under green light. Red light resulted in higher steroid and gonadotropin concentrations and higher neuropeptide mRNA expression (10). Similar results recorded in Japanese quail exposed to Red light reached sexual maturity two weeks earlier than those exposed to blue or green light (8). 


\section{Egg production}

Table 4 and Figure 1 were illustrated the hen day egg production (HDEP \%) of Japanese quails subjected to different light color treatments for six weeks after complete sexual maturity. There was no difference in HDEP among different light treatments during the first week of egg production. However, red light treatment birds had significantly higher HDEP percentage from the $2^{\text {nd }}$ week till the $6^{\text {th }}$ week of egg production, followed by white color treated group while the lowest HDEP\% was recorded for green light treated group. The total HDEP percentage was significantly higher in red light treatments than white and green light treatments where the highest HDEP percentage recorded for red light $(79.76 \%)$ and the lowest HDEP percentage recorded for green light $(66.16 \%)$. These results are similar to those reported by Baxter et al. (10) and Hassan et al. (11) who found that red monochromatic light improved egg production of the laying hens more than blue or green treatments whereas the white light had an intermediate effect. Moreover, Yang et al. (22) reported that highest cumulative egg production values of laying hens occurred in the red-light treated birds. The same results found in Japanese quails brooded and kept for the 16-week production period under red or white light laid significantly more eggs than those brooded and kept under green or blue light (8).

The present study revealed that long-wavelength light (red and white) expedited the age of sexual maturation (ASM) and increased level of egg production in birds, while short wavelength light (green) delayed sexual maturation and reduced egg production. These observations are similar to those of Mobarkey et al. (23), who found that long wavelengths (red light) contain more energy so they are able to penetrate through the skull and brain tissue and stimulate the hypothalamus to produce gonadotropin releasing hormone. As such, hypothalamic photoreceptors might be stimulated by lower wavelength but high intensity of blue/green light (24). As well, it was suggested that stimulation of retinal photoreceptors by green light might be able to inhibit reproduction (25); the possible mechanisms for such inhibition still unclear; however, contribution of serotonin is suggested due to its synthesis in hypothalamus and retina (23).

\section{Egg quality}

Some external and internal egg quality parameters of Japanese quails subjected to different treatments of light color were presented in Table 5. Egg weights of white light treated hens were heavier $(\mathrm{P}<0.05)$ than those treated with green and red light colors (14.52, 13.72 and $13.26 \mathrm{~g}$, respectively). The same results were reported by Er et al. (26), who found that egg weight was significantly higher in white and green light than Red one. In addition, Hassan et al. (11) found higher egg weight under green light than that under red light. However, other reports found that light color did not affect the average egg weight during the laying period (8, 27). Non-significant differences for egg shape index among different light colors. However, there were significant differences in egg length and width. Also, non-significant difference of the egg shape index between light treatments was recorded (22). On the other hand, white treated hens showed the highest egg volume $\left(12.34 \mathrm{~cm}^{3}\right)$ and shell \% (21.08\%). The results agreed with those reported by Pyrzak et al. (28), who found shell quality and percent of the shell did not affect by red, green and blue light treatments of the White Leghorns laying hens.

Hens treated with green and red light colors produce eggs with higher albumen plus yolk, yolk index and Haugh unit (HU) than hens exposed to white light color. The result agreed with others who found non-significant difference in HU between red, green and blue light $(11,29)$, but disagreed with Yang et al. (22), who found that HU of the eggs in the whitelight treated group was significantly higher than red, green and yellow light. Moreover, non-significant differences for yolk and albumin percentage among different light colors were recorded (30). 


\section{Male and female reproductive organs}

Relative ovary weight of female Japanese quails subjected to different light colors for 14 weeks were presented in Table 6. Japanese quail females reared under red and green light recorded higher non-significant $(\mathrm{P}>0.05)$ relative ovary weights $(4.33$ and $4.27 \%$, respectively) than those reared under white light color (3.43\%). Moreover, Japanese quail males reared under red light had higher non-significant relative testicle weights than those reared under green and white light colors, in addition sperm motility of males subjected to red color were significantly higher $(\mathrm{P}<0.05)$ than those subjected to white color but not significant with those exposed to green light color. These results agreed with Kim et al. (7), who found nonsignificant difference in ovary weight at 20 weeks of age among the different light treatments. Also, Carson et al. (31) and Pyrzak et al. (32) found non-significant difference in the rate of gonadal maturation in pullets illuminated with blue, green, or red monochromatic light incandescent light. On the other hand, Hassan et al. (11) found that laying chickens exposed to red LED light presented heavier ovaries compared with those exposed to green and blue LED lights. Moreover, Woodard et al. (8) found that testes weight of male Japanese quail at five weeks of age with red light was double that of green light. While, Retes et al. (33) found that white and red LED bulbs caused higher weights of testes and higher sperm motility in the quails at 35 days of age.

\section{Hatching parameters}

Fertility and hatchability percentages of Japanese quail eggs reared under different light colors were presented in Table 7. Quails reared under red and green light colors had higher $(\mathrm{P}<0.05)$ fertility and hatchability of the total eggs than those reared under white light colors, on the other hand, non-significant differences for hatchability of fertile eggs were recorded between different treated groups. Yang et al. (22) reported better fertility percentages for the eggs produced in the green-light treated breeders, while higher hatchability was recorded for birds reared under white light color. On the other hand, Retes et al. (33) found that fertility of quail eggs produced in green light treated birds higher than white, red and blue LED treatments. While, Non-significant differences for hatchability percentages of Japanese quail eggs produced in different light colors were recorded (8).

\section{Conflict of interest}

None of the authors have any conflict of interest to declare.

\section{References}

1. Parvin R, Mushtaq MH, Kim MJ, Choi HC. Light emitting diode (LED) as a source of monochromatic light: a novel lighting approach for behavior, physiology and welfare of poultry. World's poult sci 2014; 70 (3): 543-56.

2. Kumar V, Rani S. Light sensitivity of the photoperiodic response system in higher vertebrates: wavelength and intensity effects. Indian J Experim Biol (IJEB), 1999; 11:1053-64.

3. Bedecarrats GY, Mcfarlane H, Maddineni SR, Ramachandran R. Gonadotropin-inhibitory hormone receptor signaling and its impact on reproduction in chickens. General and comparative endocrinology 2009; 163: 7-11.

4. Rozenboim I, Biran I, Uni Z, Robinzon B, Halevy O. The effect of monochromatic light on broiler growth and development. Poult sci 1999; 78, $135-8$.

5. Manser CE. Effects of lighting on the welfare of domestic poultry: A review. Anim Welfare 1996; 5:341-60.

6. Heshmatollah K. Preference of broiler chicks for color of lighting and feed. Jpn Poult Sci 2007; 44:213-9.

7. Kim MJ, Hossan SM, Akter N, Na JC, Bang $\mathrm{T}$, Kang HK et al. Effect of monochromatic light on sexual maturity, production performance and egg quality of laying hens. Avian Biol. Res 2012; 5: 16.

8. Woodard A, Moore J, Wilson W. Effect of wavelength of light on growth and reproduction in Japanese quail (Coturnix coturnix japonica). Poult Sci 1969; 48(1):118-23.

9. S hafey T, Al-Mohsen T. Embryonic growth, hatching time and hatchability performance of meat breeder eggs incubated under continuous green light. Asian Aust J Anim Sci 2002; (15): 1702-7. 
10. Baxter M, Joseph N, Osborne V, Bedecarrats G. Red light is necessary to activate the reproductive axis in chickens independently of the retina of the eye. Poult sci 2014; (93): 1289-97.

11. Hassan MR, Sultana S, Choe HS, Ryu KS. Effect of monochromatic and combined light color on performance, blood parameters, ovarian morphology and reproductive hormones in laying hens. Italian J Anim Sci 2013; 12:3, DOI: 10.4081/ ijas.2013.e56.

12. Karousa MM, Ahmed SA, Elaithy SM, Elgazar EA. Effect of housing system and sex ratio of quails on egg production, fertility and hatchability. Benha vet med 2015; (28): 241-7.

13. NRC. National Research Council: Nutrient requirements of poultry. 9th Ed. National Academy Press. Washington, DC 1994.

14. Brody S. Bioenergetics and growth. Reinhold Publishing Corporation 1945; New York.

15. Taha AE. Laying performance of Japanese quails divergently selected for body weight under different rearing and lighting systems. PhD Thesis, 2009; Fac. Of Vet. Med. Alex. Univ. Egypt.

16. SAS. Statistical user's Guide' Statistical Analysis System. 2004; INT., Cary, NC. USA.

17. Snedecor GW, Cochran WG. Statistical method, 7th Edition, The Iowa State University, Press Ames Iowa, 1981; U.S.A.

18. Li D, Zhang L, Yang M, Yin H, Xu H, Trask JS, et al. The effect of monochromatic light-emitting diode light on reproductive traits of laying hens. J Appl Poult Res 2014; 23: 367-75.

19. Reddy IJ, David CG, Selvaraju S, Mondal S, Kiran GR. GnRH-1 mRNA, LH surges, steroid hormones, egg production, and intersequence pause days alter in birds exposed to longer wavelength of light in the later stages of production in Gallus gallus domesticus. Trop anim health prod 2012; 44 : 1311-7.

20. Tarhyel R, Tanimomo BK, Hena SA. Effect of sex, color and weight group on carcass characteristics of Japanese quail. Scientific Journal of Animal Science 2012; 1(1): 22-7

21. Olawumi SO. Effects of Housing and Sex on Growth Performance of Coturnix Quails in the Derived Savannah Zone of Nigeria. International Journal of Agriculture, Forestry and Fisheries 2015; 3 (6): 227-31.

22. Yang YF, Jiang JS, Pan JM, Ying YB, Wang XS, Zhang ML et al. The relationship of spectral sensitivity with growth and reproductive response in avian breeders (Gallus gallus). Sci reports 2016; 14 (6):19291. doi: 10.1038/srep19291

23. Mobarkey N, Avital N, Heiblum R, Rozenboim I. The role of retinal and extra-retinal photostimulation in reproductive activity in broiler breeder hens. Domestic animal endocrinology 2010; 38: 235-43.

24. Pang SF, Ralph C, Reilly DP. Melatonin in the chicken brain: its origin, diurnal variation, and regional distribution. General and comparative endocrinology1974; 22: 499-506.

25. Mobarkey N, Avital N, Heiblum R, Rozenboim I. The Effect of Parachlorophenylalanine and Active Immunization Against Vasoactive Intestinal Peptide on Reproductive Activities of Broiler Breeder Hens Photostimulated with Green Light. Biology of reproduction2013; 88 (83): 1-7.

26. Er D, Wang Z, Cao J, Chen Y. Effect of monochromatic light on the egg quality of laying hens. J Appl Poult Res 2007; 16: 605-12.

27. Rozenboim I, Zilberman E, Gvaryahu G. New monochromatic light source for laying hens. Poult Sci 1998; 77: 1695-8.

28. Pyrzak R, Snapir N, Goodman G, Perek M. The effect of light wavelength on the production and quality of eggs of the domestic hen, Theriogenology 1987; 28: 947-60.

29. Nunes KC, Garcia RG, Nääs IA, Eyng C, Caldara FR, Sgavioli S et al. Effect of Led Lighting Colors for Laying Japanese Quails. Revista Brasileira de Ciência Avícola 2016; 18(SPE): 51-56.

30. Borille R, Garcia RG, Nääs IA, Caldara FR, Santana MR. Monochromatic light-emitting diode (LED) source in layers hens during the second production cycle. Revista Brasileira de Engenharia Agrícola e Ambiental 2015; 19(9): 877-81.

31. Carson JR, Junnila WA, Bacon BF, Sexual maturity and productivity in the chicken as affected by the quality of illumination during the growing period. Poult Sci 1958; 37: 102-12.

32. Pyrzak R, Siopes T. The effect of light color on egg quality of turkey hens in cages Poult Sci 1986; 65: 1262-7.

33. Retes PL, Espósito M, das Neves DG, Viana AG, Coelho LM, Bobadilla-Mendez MF et al. Influence of different types of lamps on the reproductive development of male Japanese quail (Coturnix coturnix japonica). Theriogenology 2017; 94: 5963. 